\title{
Effects of Chitosan and Aloe Vera Gel Coatings on the Preservation Characteristics of Cucumber Samples
}

\author{
AJIBOYE Adeyinka Elizabeth, GBOYINDE Phebe Mimololuwa* \\ Department of Biosciences and Biotechnology, College of Pure and Applied Science, Kwara State University, \\ Malete, Kwara State, Nigeria
}

* Corresponding Author email:

$$
\text { pheboung@yahoo.com }
$$

Article Histary

Received: 29 February 2020

Revised: 25 April 2020

Accepted: 01 June 2020

Published: 12 June 2020

Student(s)

- Phebe Mimololuwa GBOYINDE

Academic Year: 2017-18

Course Level: Master

Course Name: M.Sc. (Microbiology)

Course year: Final Year

Mentor(s)

- $\quad$ Adeyinka Elizabeth AJIBOYE

\section{ABSTRACT}

This study evaluated the effect of Chitosan and Aloe vera gel coatings on the preservation of selected cucumber samples. Chitosan was produced from orange-crab shells with $76 \%$ degree of deacetylation while homogenized Aloe vera gel extracted from the plants was thermally pre-treated at $70{ }^{\circ} \mathrm{C}$ for 30 minutes. Coatings were applied using dipping techniques and air-dried before storage in discrete plots under ambient conditions. The study estimated physicochemical, nutritional and microbiological qualities of the coated and uncoated samples for a period of 4 weeks using standard procedures. Chitosan and Aloe vera gel had antimicrobial effect on the cucumber samples at week three while Chitosan- Aloe vera mix had more antimicrobial effect on the cucumber samples at week four of storage period. Eight bacterial and seven fungal isolates were obtained from the chitosan and Aloe vera coatings on the cucumber samples namely Aeromonas, Bacillus, Pseudomonas, Escherichia, Proteus, Klebsiella, Serratia, Enterobacter, Aspergillus, Penicillium, Fusarium, Rbizopus and, Saccharomyces; with Bacillus subtilis and Aspergillus niger as most occurring bacterial and fungal species respectively. Chitosan, Aloe vera and Chitosan-aloe vera mix coated samples had moisture content, protein content and carbohydrate retention of $95.09 \pm 0.01 \%, 1.31 \pm 0.09 \%$ and $0.46 \pm 0.14 \% ; 94.67 \pm 0.14 \%, 0.65 \pm 0.03 \%$ and $1.61 \pm 0.44 \%$; $93.76 \pm 0.09 \%, 1.27 \pm 0.66 \%$, and $0.69 \pm 0.51 \%$ respectively. It can be concluded that Chitosan and Aloe vera gel coatings are effective in preservation of cucumbers with significant retention of nutrients and reduction in microbial contamination.

Keywords: chitosan, aloe vera gel, cucumber, preservation and microorganisms

\section{Introduction}

Cucumber is a non-climacteric fruit vegetable that contains more than $90 \%$ water which is a principal factor affecting fruit quality during transportation, storage, and marketing [1]. It is one of the most important and popular vegetable crops all over the world including Nigeria. It could be grown in two growing seasons, 
autumn and spring under plastic house conditions. Cucumber, which is largely consumed as fresh fruit, vegetable in salads, or pickled product, is attracting more interest as a minimal processed fruit [2].

The increase in the rate of decay has posed a significant challenge to the storage of fruits and vegetables which had leads to loss of nutrient and also the spread of microorganisms which are responsible for degradation [3], leading to yearly losses of fresh produce due to inappropriate storage conditions across the world [4]. The deterioration in the quality of fruits and vegetables is characterized by spoilage with visible manifestations such as weight loss, change in colour, decay, and shrinkage among others which is due to some environmental effects, including contamination by bacteria and fungi. Many of these microorganisms, in particular pathogens are able to cause spoilage of foods leading to severe health problems in consumers, especially if food is handled and distributed under inappropriate conditions. The effect of spoilage brings about decrease in the commercial value of fruits and vegetables leading to unavailability to the consumers as well as low profit for the producers.

Recently, fruits and vegetables quality preservation and shelf life extension are maintained by the use of edible coatings with the effect of retarding some physiological processes such as respiration and transpiration [5]. Among different post-harvest management strategies of fresh fruit handling, use of edible coatings have been reported to be very useful as an environment friendly technology [6]. Generally, film from polysaccharides such as alginate, chitosan, proteins and lipids are commercially used and could be applied to protect the whole fruit [7].

Chitosan is a high-molecular-weight carbohydrate polymer produced by the deacetylation of chitin [8]. It is widely applied in the storage of fruits and vegetables as a semi-permeable film that regulates the internal atmosphere and reduces the transpiration, thus extending their shelf life [8]. Results of different studies had proved the effectiveness of chitosan in retarding the ripening process of strawberries [9], sweet cherries [10], papaya [5], and carambola [11].

The role of microorganisms in fruits and vegetables spoilage, foodborne diseases and food insecurity are the reasons why this study assess the effect of Chitosan and Aloe vera gel coatings on cucumber (Cucumis sativa) in extending the shelf life and preventing spoilage hence making them available to the consumers as well as salvaging issues of insecurity and profit loss and also preventing health related issues associated with consumption of spoilt food.

This study's aim is to determine the effect of chitosan and Aloe vera gel coatings on preservation characteristics of cucumber under the following objectives:

i. determine the microbial load on cucumber samples coated with chitosan, aloe-vera and chitosanaloe vera mix for 4 weeks;

ii. Isolate and identify the microorganisms isolated from cucumber samples coated with chitosan and aloe-vera coated cucumber samples;

iii. determine the physicochemical properties of cucumber samples before and after storage;

iv. determine the discrete and combined effects of chitosan and Aloe vera gel coating on cucumber preservation;

\section{Materials and Methods}

\subsection{Collection and Processing of Samples}

The samples for this study were crab shell, cucumber and Aloe vera. Crab shells were purchased from Makoko market, Ebute-Meta, Lagos State. The shells were carefully sorted, washed and air dried for about 10 days after which they were milled and stored in an airtight container at room temperature $\left(28 \pm 2{ }^{\circ} \mathrm{C}\right)$ until further use. Cucumber samples were also obtained and kept under room temperature for further use. Fresh Aloe vera leaves were harvested and prepared. The Aloe-vera gel was pasteurized at $70{ }^{\circ} \mathrm{C}$ for 45 minutes. It was then cooled immediately at ambient temperature. To facilitate coating, the gel was thickened using already prepared sterilized edible starch. 


\subsection{Demineralization, Deproteinization and Deacetylation of Milled Crab Shell}

About $3.0 \mathrm{~kg}$ of milled crab shell was treated with 5 litres of $1.0 \mathrm{M}$ hydrochloric acid for about 36 hours and was washed till $\mathrm{pH}$ of 7.0. The demineralized milled crab shell was treated with $1.0 \mathrm{M} \mathrm{NaOH}$ solution for about 36 hours after which it was washed thoroughly with water until a neutral $\mathrm{pH}$ of 7.0 was attained [12]. The deproteinized milled crab shell was treated with 5 litres of $12.5 \mathrm{M} \mathrm{NaOH}$ for 24 hours after which it was washed thoroughly with water until a neutral $\mathrm{pH}$ of 7.0 was attained [13].

Solubility test was carried out after deacetylation by dissolving $5 \mathrm{~g}$ of the milled crab shell in $50 \mathrm{ml}$ of $1 \%$ acetic acid. The milled crab shell was bleached using 5 litres of 30\% sodium hypochlorite (NaOCL) for 24 hours after which it was thoroughly washed in water until $\mathrm{pH}$ of 7.0 was attained. Sample was oven dried after bleaching and kept at room temperature for further use [14].

\subsection{Coating of Cucumber Samples}

The cucumber samples were divided into four different treatments which include control, discrete and combined chitosan and Aloe vera gel, these were coated using dipping method. The coated cucumber samples were stored in different baskets at $28 \pm 2{ }^{\circ} \mathrm{C}$ for four weeks.

\subsection{Physicochemical and Proximate Analysis}

The cucumber samples were analyzed for some physicochemical compositions such as moisture content, ash content, crude fat, crude fibre, crude protein which were determined using AOAC methods [15]. Total carbohydrate was determined by the Difference Method. The difference that remained after subtracting all values of moisture, protein, fat, and ash from $100 \mathrm{~g}$ of the sample was total carbohydrate [16]. $\beta$-carotene, lycopene [17], total soluble solid, total titratable acid and $\mathrm{pH}$ [18].

\subsection{Microbiological Analysis}

Materials including respective growth media were appropriately sterilized and bacteria, fungi and coliforms were isolated from cucumber samples. Pouring method of isolation was used. Characterization and identification was carried out using morphological characterization as well as biochemical tests which include gram staining [19], catalase test, coagulase test, citrate test, indole test, starch hydrolysis, oxygen relationship and sugar fermentation test [20].

\subsection{Statistical Analysis}

Results generated from the study were expressed as mean \pm standard deviation of three replicate determinations. Statistical analysis was performed on the data using one-way analysis of variance (ANOVA) using statistical package for social sciences (SPSS) software and differences in means were compared by the Duncan's multiple range test. Significance was accepted at $\mathrm{P} \leq 0.05$.

\section{Results and Discussion}

The result of this study showed a slight reduction in moisture content across the treatment with chitosan and aloe vera mix having the lowest content. Mohammed et al. [21] who had similar research also observed a decrease in moisture content and hence reported that food with lower moisture content has longer shelf life. Cucumber samples used as control had a relatively high $\mathrm{pH}$ compared to other treatments and treatment three and four had higher total titratable acid compare to other treatments. Low $\mathrm{pH}$ and high total titratable acid had been reported to be an advantage as it discourages microbial growth [21].The total soluble solid was increased at the end of the storage period compared to the value before coating. This might be due to the breakdown of starch into simple sugar as sugars are the primary constituents of soluble solid concentration [22]. In this study, higher total soluble solids were observed in all treated samples [22]. Also, the antioxidant properties of beta-carotene and lycopene increased at the end of a storage period. These properties have been reported to help protect our body from certain diseases as well as preserve the health of our skin, eyes and immune system [23]. It is shown that cucumber with chitosan-aloe vera gel had 
highest Ash content compare with other coats. The ash content, an organic aspect of food, gives an indication of the range of mineral elements present in food materials [24]. The ash content obtained at the end of storage was higher than those obtained by Dima et al. [25] Crude protein increased generally across the treatment with the treatment with chitosan- aloe vera gel coating as one of the highest with significant similarity to the protein content of the sample before coating (Table 1).

Table 1: Physicochemical Characteristics of Cucumber Treatment

\begin{tabular}{llllll}
\hline Physicochemical Parameters & BC & T1 & T2 & T3 & T4 \\
MC (\%) & $96.21 \pm 0.04^{\mathrm{a}}$ & $94.07 \pm 0.04^{\mathrm{b}}$ & $95.09 \pm 0.01^{\mathrm{b}}$ & $94.67 \pm 0.14^{\mathrm{c}}$ & $93.76 \pm 0.09^{\mathrm{c}}$ \\
ASH (\%) & $0.54 \pm 0.04^{\mathrm{a}}$ & $0.99 \pm 0.01^{\mathrm{a}}$ & $0.90 \pm 0.06^{\mathrm{a}}$ & $0.92 \pm 0.19^{\mathrm{ab}}$ & $1.21 \pm 0-41^{\mathrm{ab}}$ \\
FAT (\%) & $1.27 \pm 0.45^{\mathrm{a}}$ & $1.02 \pm 0.01^{\mathrm{b}}$ & $0.10 \pm 0.01^{\mathrm{bc}}$ & $0.54 \pm 0.01^{\mathrm{c}}$ & $1.25 \pm 0.00^{\mathrm{bc}}$ \\
Fibre (\%) & $0.25 \pm 0.00^{\mathrm{a}}$ & $2.01 \pm 0.01^{\mathrm{b}}$ & $1.22 \pm 0.00^{\mathrm{bc}}$ & $1.60 \pm 0.05^{\mathrm{d}}$ & $1.80 \pm 0.35^{\mathrm{d}}$ \\
Protein (\%) & $0.49 \pm 0.01^{\mathrm{ab}}$ & $1.13 \pm 0.01^{\mathrm{b}}$ & $1.31 \pm 0.09^{\mathrm{c}}$ & $0.65 \pm 0.03^{\mathrm{d}}$ & $1.27 \pm 0.66^{\mathrm{ad}}$ \\
CHO (\%) & $1.25 \pm 0.10^{\mathrm{ab}}$ & $0.77 \pm 0.03^{\mathrm{c}}$ & $0.46 \pm 0.14^{\mathrm{c}}$ & $1.61 \pm 0.44^{\mathrm{a}}$ & $0.69 \pm 0.51^{\mathrm{c}}$ \\
pH & $6.38 \pm 0.33^{\mathrm{a}}$ & $7.20 \pm 0.00^{\mathrm{a}}$ & $6.98 \pm 0.00^{\mathrm{a}}$ & $6.85 \pm 0.01^{\mathrm{a}}$ & $6.65 \pm 0.00^{\mathrm{a}}$ \\
TTA (\%) & $0.08 \pm 1.42^{\mathrm{a}}$ & $0.04 \pm 0.00^{\mathrm{b}}$ & $0.04 \pm 0.00^{\mathrm{b}}$ & $0.06 \pm 0.00^{\mathrm{b}}$ & $0.08 \pm 0.00^{\mathrm{c}}$ \\
TSS ( $\mathbf{0}$ Brix) & $1.33 \pm 0.117^{\mathrm{a}}$ & $3.00 \pm 0.00^{\mathrm{b}}$ & $3.20 \pm 0.00^{\mathrm{b}}$ & $3.97 \pm 0.03^{\mathrm{b}}$ & $3.93 \pm 0.33^{\mathrm{c}}$ \\
Lycopene (mg/100 ml) & $0.04 \pm 0.00^{\mathrm{ab}}$ & $0.13 \pm 0.03^{\mathrm{c}}$ & $0.25 \pm 0.03^{\mathrm{c}}$ & $0.12 \pm 0.01^{\mathrm{c}}$ & $0.11 \pm 0.06^{\mathrm{a}}$ \\
$\beta$-carotene (mg/100ml) & $0.04 \pm 0.00^{\mathrm{a}}$ & $0.40 \pm 0.00^{\mathrm{b}}$ & $0.53 \pm 0.01^{\mathrm{b}}$ & $0.29 \pm 0.01^{\mathrm{b}}$ & $0.23 \pm 0.00^{\mathrm{a}}$ \\
\hline
\end{tabular}

Values are means of triplicate readings and standard deviation. Values in the same row having different superscript are significantly different at $\mathrm{P} \leq 0.05$.

Keys: $\mathbf{B C}=$ Before coating; $\mathbf{T} 1=$ Control; $\mathbf{T} \mathbf{2}=\mathbf{0 . 2 5} \mathbf{g} / \mathbf{m l}$ Chitosan coating; $\mathbf{T 3}=\mathbf{2} \mathbf{~ m l} / \mathbf{m l}$ Aloe vera coating; $\mathbf{T 4 = 0 . 5} \mathbf{~ g / m l ~ C h i t o s a n - ~ A l o e ~}$ vera coating; $\mathbf{M C}=$ Moisture Content $\mathbf{C H O}=$ Carbohydrate; TTA= Total Titratable Acid, $\mathbf{T T S}=$ Total Soluble solid

Table 2: Probable Identification of Bacterial Isolates across Sample Treatments

\begin{tabular}{|c|c|c|c|c|c|c|c|c|c|c|c|c|}
\hline \multirow[t]{2}{*}{ Isolates } & \multirow{2}{*}{ 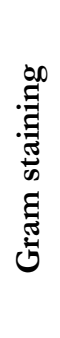 } & \multirow[b]{2}{*}{$\underset{\tilde{\Xi}}{\tilde{\Xi}}$} & \multirow[b]{2}{*}{ 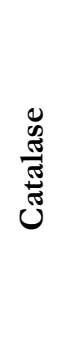 } & \multirow[b]{2}{*}{ 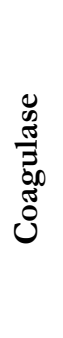 } & \multirow[b]{2}{*}{$\underset{0}{\stackrel{\Xi}{*}}$} & \multirow[b]{2}{*}{ 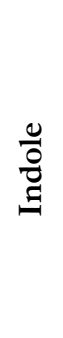 } & \multirow{2}{*}{ 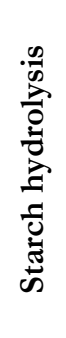 } & \multirow{2}{*}{ 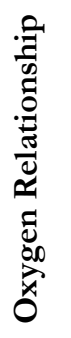 } & \multicolumn{4}{|c|}{ Sugar fermentation } \\
\hline & & & & & & & & & 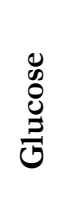 & 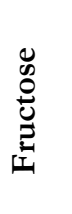 & 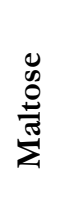 & $\begin{array}{c}\text { Probable } \\
\text { organisms }\end{array}$ \\
\hline B1 & - & Rods & + & - & + & - & + & FA & $\mathrm{A}$ & $\mathrm{A}$ & NA & Proteus sp. \\
\hline B2 & - & $\begin{array}{l}\text { Long } \\
\text { rods }\end{array}$ & + & - & + & - & - & $\mathrm{Ae}$ & A & A & A & Pseudomonas sp. \\
\hline B3 & - & Rods & + & - & - & + & + & $\mathrm{FA}$ & A & A & A & Escherichia coli \\
\hline B4 & - & Rods & + & - & + & - & + & FA & AG & A & $\mathrm{A}$ & Enterobacter sp. \\
\hline B5 & - & Rods & + & - & - & - & - & $\mathrm{Ae}$ & A & NA & NA & Aeromonas sp. \\
\hline B6 & - & Rods & + & - & + & - & - & $\mathrm{Ae}$ & A & A & A & K. pneumoniae \\
\hline B7 & + & Rods & + & - & + & - & + & FA & A & $\mathrm{A}$ & $\mathrm{A}$ & Bacillus sp. \\
\hline B8 & - & Rods & + & - & + & - & - & FA & A & $\mathrm{A}$ & A & Serratia sp. \\
\hline
\end{tabular}

Key: $+=$ positive,$-=$ negative, $\mathrm{A}=$ acid production, $\mathrm{Ae}=$ aerobe, $\mathrm{FA}=$ facultative anaerobe, $\mathrm{AG}=$ acid and gas production, $\mathrm{NA}=$ no acid and gas production 
Eight different bacteria were isolated and identified as probable organisms (Table 2) which includes, bacteria of the genus Aeromonas, Bacillus, Pseudomonas, Escherichia, Proteus, Klebsiella, Serratia, and Enterobacter [26], Pseudomonas and Bacillus have been reported as the most occurring organisms on the cucumber samples. Raja et al. [27] investigated that Pseudomonas sp. and Bacillus sp. were dominantly found in both local and super market fruits and vegetables samples. Kumar et al. [28] also isolated and characterized seven bacterial isolates which includes Bacillus, Klebsiella, Pseudomonas, E.coli, Lactobacillus, Staphylococcus and Micrococcus on the basis of morphology and biochemical reactions. Their reports also show that Bacillus, Klebsiella and Pseudomonas were the dominating species in the spoilage of every categories of food material. The seven fungal isolates (Table 3) obtained from the cucumber samples also agree with the findings of Mbajiuka et al. [29] who isolated fungi of the genus Aspergillus, Penicillium, Fusarium, Rhiropus and Saccbaromyces. Li-Cohen and Bruhn [30] reported that species of fungi associated with fruits and vegetables are of the genus Aspergillus, Penicillium, Fusarium and Rhizopus. Microbial invasion of the samples was also seen in the research carried out by Nasrin et al. [31] who reported microbial incidence on bell pepper after days of storage. Also, the controlled microbial incidence also supported the work carried out by Olawuyi et al. [2].

Table 3: Characterization and Probable Identification of Fungal Isolates across Sample Treatments

\begin{tabular}{|c|c|c|}
\hline $\begin{array}{l}\text { Fungal } \\
\text { Isolates }\end{array}$ & Colonial morphology and microscopy & $\begin{array}{c}\text { Tentative } \\
\text { Identification }\end{array}$ \\
\hline F1 & $\begin{array}{l}\text { Yellow-green, flat, granular, and radially grooved colonies on potato dextrose agar; its } \\
\text { conidial heads are radiate with hyaline and slightly rough conidiophores. Its conidia } \\
\text { are globose and light green in color }\end{array}$ & Aspergillus flavus \\
\hline F2 & $\begin{array}{l}\text { Relatively fast growing mould with a characteristic black color; the conidial head is } \\
\text { large, black and spherical. Smooth and colorless conidiophores, connects spherical } \\
\text { vesicles which are covered by two layers of phialides all over their surface. The conidia } \\
\text { are globose and rough-walled. }\end{array}$ & Aspergillus niger \\
\hline $\mathbf{F 3}$ & $\begin{array}{l}\text { Rapidly growing colonies with cottony yellowish taint growth covering the agar } \\
\text { surface densely; identical microscopic view to plants' roots was observed. Its } \\
\text { sporangiophores arose from nodes above the rhizoids and hangs multispored and } \\
\text { globose sporangia. A collapsed apophyses and columella formed an observed } \\
\text { umbrella-like structure. Its sporangiospores and sporangiophores are brown in color. }\end{array}$ & Rhizopus stolonifer \\
\hline $\mathbf{F 4}$ & $\begin{array}{l}\text { Green colonies on potato dextrose agar with a reverse grey colour. They possess short } \\
\text { conidia heads and are biserate; conidia are globose and rough-walled while } \\
\text { conidiophores are smooth-walled. }\end{array}$ & Aspergillus nidulans \\
\hline F5 & $\begin{array}{l}\text { Fast growing light green colonies on potato dextrose agar with a convex growth } \\
\text { pattern. Single-celled conidia are borne on phialides arising from branched and non- } \\
\text { branched metulae, which presents the brush or broom-like appearance. Conidiophores } \\
\text { are hyaline, smooth-walled; globose conidia are hyaline. }\end{array}$ & Penicillium sp. \\
\hline F6 & $\begin{array}{l}\text { Fast growing cottony mycelium with pinkish taints. The phialides are slender; sickle- } \\
\text { shaped macroconidia are hyaline, multicelled with an elongated apical cell. }\end{array}$ & Fusarium sp. \\
\hline F7 & $\begin{array}{l}\text { Glistering discrete cream colonies on potato dextrose agar resembling bacterial } \\
\text { colonies. Tiny cells continually elongate and divide to give daughter cells, filling } \\
\text { microscope field within short time-intervals. }\end{array}$ & Saccharomyces sp. \\
\hline
\end{tabular}

In figure 1 and 2, the results showed the increase growth at week two and subsequently decrease at week three and four. At week four, treatment four with the chitosan- aloe vera gel coat had a reduced microbial load compared to other treatments. Fungal count was relatively high at week two which could be due to the presence of moisture [32] and the load was reduced at week four especially on samples coated with chitosan-aloe vera gel mix. A rise in microbial load within the storage period could be due to certain environmental factors or contaminations [33]. The presence of active compounds in aloe vera gel could be a reason for limited microbial growth [34]. There was controlled microbial growth in the samples coated with chitosan and aloe vera but higher efficacy was observed in the Chitosan-Aloe vera mix which indicate 
the antimicrobial efficacy of the coats used. This can be supported with the work of Olawuyi et al. [2] who reported that the coats used have the ability to alter the growth rate of microorganism.

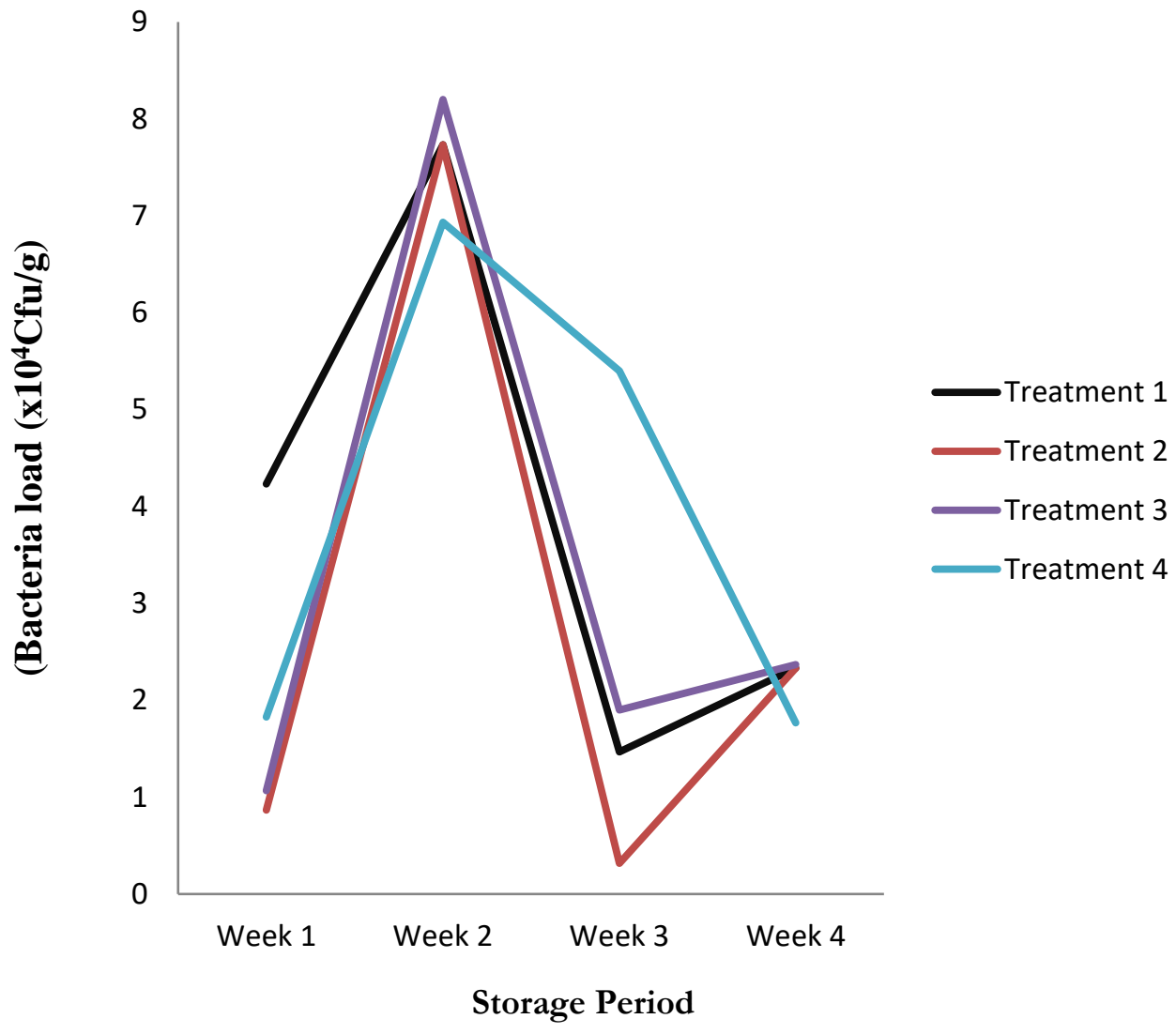

Figure 1: Bacteria load (Cfu/g) of preserved cucumbers across storage period Keys: $\mathbf{T} 1=$ Control; $\mathbf{T} 2=\mathbf{0 . 2 5} \mathrm{g} / \mathrm{ml}$ Chitosan coating; $\mathbf{T} 3=\mathbf{2} \mathrm{ml} / \mathrm{ml}$ Aloe vera coating; $\mathbf{T} 4=\mathbf{0 . 5} \mathrm{g} / \mathrm{ml}$ Chitosan- Aloe vera coating

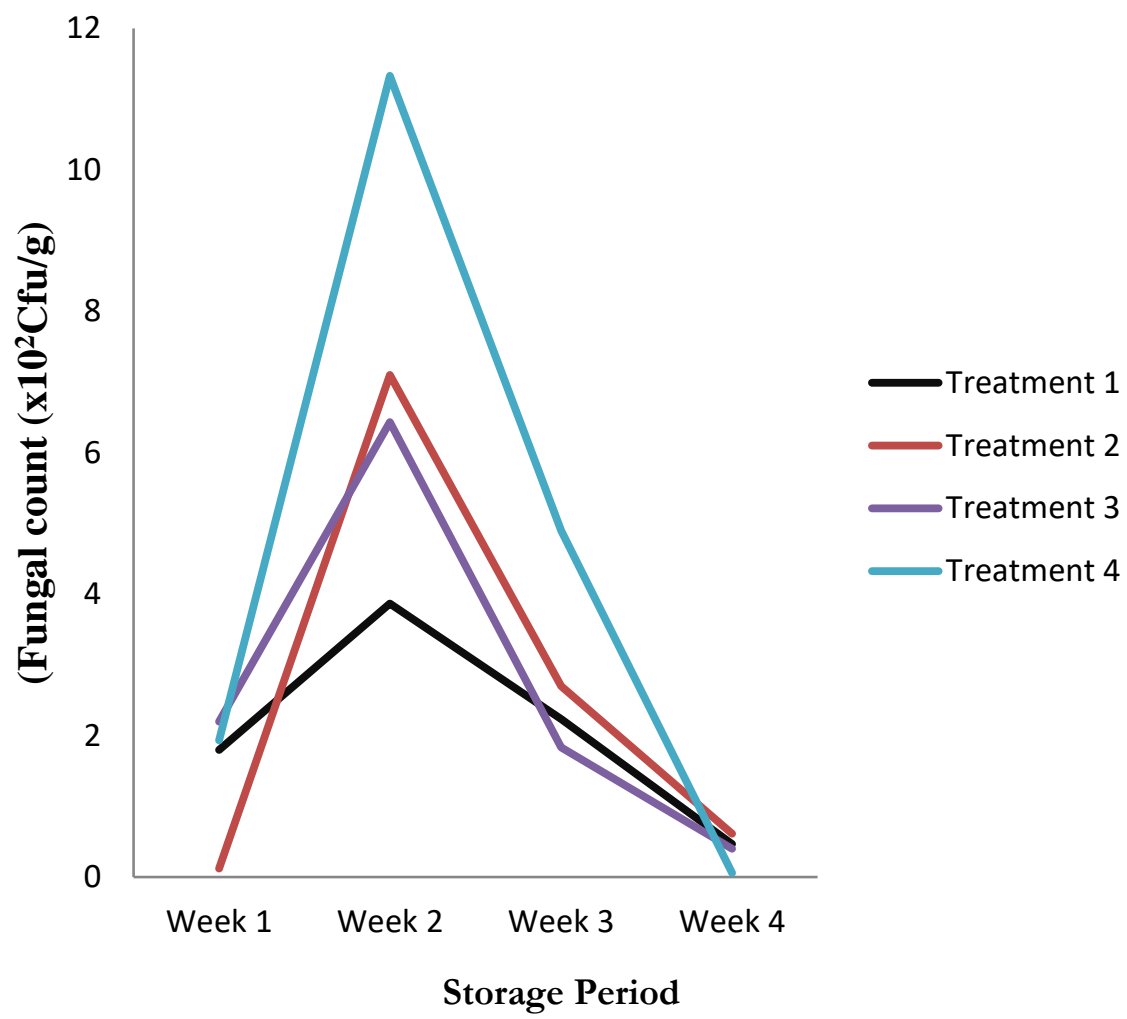

Figure 2: Fungi load (Cfu/g) of preserved cucumbers across storage period Keys: $\mathbf{T} 1=$ Control; $\mathbf{T} 2=\mathbf{0 . 2 5} \mathrm{g} / \mathrm{ml}$ Chitosan coating; $\mathbf{T} 3=\mathbf{2} \mathbf{~ m l} / \mathbf{m l}$ Aloe vera coating; $\mathbf{T} 4=\mathbf{0 . 5} \mathrm{g} / \mathrm{ml}$ Chitosan- Aloe vera coating 
The results of this study support the research of Olawuyi et al. [2]; Ortego-toro et al. [35]; Talens et al. [36] and Perdonesa et al. [37] who applied chitosan and other coats to pineapple, cucumber, tomatoes, strawberry and Litchi respectively and observed decrease in microbial loads, delay ripening and elongation of shelf life. Chitosan had obvious effect on the cucumber samples [38] and [39]. Also, aloe vera gel effectiveness and its synergism with chitosan in this study also supports the work of Ortego-toro et al. [35]; Olawuyi et al. [2]; Nasrin et al. [31]; Adetunji et al. [40] and Martinez-Romeo et al. [34] who reported the reduction in the microbial count on the samples during storage period was due to its antibacterial and antifungal properties, and also its ability to prevent moisture loss, control the respiration rate, maturation development, delay oxidative browning and reduce microorganism proliferation. Also, Adetunji et al. [40] who carried out similar research confirms that the combination of aloe vera with other coat could be used to preserve the self-life of sweet orange.

\section{Conclusion}

To effectively extend the shelf life of postharvest fruit and vegetable such as cucumber, chitosan and Aloe vera-based coating is a relatively convenient and considered safe. In order to strengthen the efficacy of single coat, combining coats had been an established strategy which this study also employed, combining chitosan and Aloe vera gel in extending the shelf life of cucumber samples. Although majority of researches on coating had been carried out in a relatively cold environment which had led to their respective outcomes, this research at some point underwent slight change in temperature due to climatic change which would have contributed in one way to its outcome such as microbial increase and moisture loss. However, the coatings achieved extended shelf-life of cucumber with antimicrobial efficacy and reduced rate of biochemical degradation (nutrient loss) by chitosan, Aloe vera and chitosan-Aloe vera gel mix. The antimicrobial efficacy of the applied coatings tends to reduce microbial load thereby limiting spoilage. Also, the nutritional and physicochemical properties of cucumber samples were significantly retained. There was reduced respiration rate which lead to delayed ripening of samples as well as extending the shelf life of the samples. Hence it can be concluded that the use of chitosan and Aloe vera gel is effective in preservation of cucumber quality its extending shelf life. These coats may not just be effective in cucumber preservation but also in preservation of other fruits and vegetables. Subsequent researches should be channelled toward the preservation of cucumbers in hot seasons as heat could be a major cause of early spoilage of fruits and vegetables. Also, concentration of coats that should be used at different atmospheric condition such as the temperature and relative humidity should also be researched in order to achieve more successes in salvaging the issue of food insecurity globally.

\section{Competing Interests}

The authors declared that no conflict of interest exist in this publication.

\section{How to Cite this Article:}

A. Ajiboye and P. Gboyinde, "Effects of Chitosan and Aloe Vera Gel Coatings on the Preservation Characteristics of Cucumber Samples", Adv. J. Grad. Res., vol. 8, no. 1, pp. 82-90, Jun. 2020. https://doi.org/10.21467/ajgr.8.1.82-90

\section{References}

[1] D. L. Smith, J. R. Stommel, R. W. M. Fung, C. Y. Wang, and B. D. Whitaker, "Influence of cultivar and harvest method on postharvest storage quality of pepper (Capsicum annuum L.) fruit," Postharvest Biology and Technology, vol. 42, no. 3, pp. 243-247, June 2006. http://dx.doi.org/10.1016/j.postharvbio.2006.06.013

[2] I. F. Olawuyi, J. J. Park, J. J. Lee and W. Y. Lee, "Combined effect of chitosan coating and modified atmosphere packaging on freshcut cucumber," Food Science Nutrition, vol. 7, pp. 1043-1052, Feb. 2019. https://doi.org/10.1002/fsn3.937

[3] Y. Xing, Q. Xu, S. X. Yang, C. Chen, Y. Tang, S. Sun and X. Li, "Preservation mechanism of chitosan-based coating with cinnamon oil for fruits storage based on sensor data," vol. 16, pp. 1111, 2017.

[4] Y. Xing, W. Li, Q. Wang, X. Li, Q. Xu, X. Guo, X. Bi, X. Liu, Y. Shui, H. Lin and H. Yang, "Antimicrobial Nanoparticles Incorporated in Edible Coatings and Films for the Preservation of Fruits and Vegetables," Molecules, vol. 24, pp. 1695, April. 2019. https://doi:10.3390/molecules24091695 
[5] A. Ali, M. T. M. Muhammad, K. Sijam, and Y. Siddiqui, "Effect of chitosan coatings on the physicochemical characteristics of Eksotika II papaya (Carica papaya L.) fruit during cold storage," Food Chemistry, vol. 124, no. 2, pp. 620-626, Jan. 2011. https://doi.org/10.1016/j.foodchem.2010.06.085

[6] P. Kumar and S. Sethi, "Edible Coating for Fresh Fruit: A Review," International Journal of Current Microbiology and Applied Sciences, vol. 7, no. 05, pp. 2619-2626, May. 2018. https://doi.org/10.20546/ijcmas.2018.705.303

[7] C. Chen, X. Peng, R. Zeng, M. Chen, C. Wan, and J. Chen, "Ficus hirta fruits extract incorporated into an alginate-based edible coating for Nanfeng mandarin preservation," Scientia Horticulturae, vol. 202, pp. 41-48, Feb. 2016. http://dx.doi.org/10.1016/j.scienta.2015.12.046 0304-4238

[8] F. Varasteh, K. Arzani, M. Barzegar, and Z. Zamani, "Pomegranate (Punica granatum L.) fruit storability improvement using prestorage chitosan coating technique," Journal of Agricultural Science and Technology, vol. 19, no. 2, pp. 389-400, Mar. 2017.

[9] K. Martínez, M. Ortiz, A. Albis, C. Gilma Gutiérrez Castañeda, M. Valencia, and C. G. Tovar, "The effect of edible chitosan coatings incorporated with Thymus capitatus essential oil on the shelf-life of strawberry (fragaria $x$ ananassa) during cold storage," Biomolecules, vol. 8, no. 4, pp. 155, Nov. 2018. https://doi.org/10.3390/biom8040155

[10] M. Petriccione, F. De Sanctis, M. S. Pasquariello, F. Mastrobuoni, P. Rega, M. Scortichini, and F. Mencarelli, "The effect of chitosan coating on the quality and nutraceutical traits of sweet cherry during postharvest life," Food and Bioprocess Technology, vol. 8, no. 2, pp. 394-408, Sept. 2015. https://doi.org/10.1007/s11947-014-1411-x

[11] N. B. Gol, M. L. Chaudhari, and T. V. R. Rao, "Effect of edible coatings on quality and shelf life of carambola (Averrhoa carambola L.) fruit during storage," Journal of Food Science and Technology, vol. 52, no. 1, pp. 78-91, Jan. 2015. https://doi.org/10.1007/s13197-013-0988-9

[12] M. Huang, E. Khor, and L.Y. Lim, (2004). "Uptake and cytotoxicity of chitosan molecules and nanoparticles," Effects of molecular weight and degree of deacetylation. Pharmaceutical Resource, vol. 21, no. 2, pp. 344-53, Feb. 2004. https://https://doi.org/10.1023/b:pham.0000016249.52831.a5

[13] R. A. Muzzarelli, and R. Rochetti, "Determination of the degree of deacetylation of chitosan by first derivative ultraviolet spectrophotometry," Journal of Carbohydrate Polymer, vol. 5, pp. 461-72, May, 1985.

[14] M. H. Mohammed, T. Williams, "Extraction of chitin from prawn shells and conversion to low molecular mass chitosan," Food hydrocolloids, vol. 31, no. 2, pp. 166-171, June 2013. http://dx.doi.org/10.1016/j.foodhyd.2012.10.021

[15] AOAC, "Official Method of Analysis 17th Ed." William Horwitz. Ed. Washington, Dc, Association of Official Analytical Chemists, vol. 7, pp. 56-132, 2000.

[16] S. S. Nielsen, "Introduction to the Chemical Analysis of Foods," Jones and Bartlett Publishers International. 7 Melrose Terrace, London W6 7RL, England, vol. 142, pp. 233-246; 253, June, 1994. ISBN: 08672082609780867208269

[17] W. W Fish, P. Perkins-Veazie, and J. K. Collins, "A quantitative assay for lycopene that utilizes reduced volumes of organic solvents," Journal of Food composition and Analysis, vol. 15, pp. 309-317, June, 2002. https://doi.org/10.1006/jfca.2002.1069

[18] AOAC, "Official Method of Analysis 18th Ed." William Horwitz. Ed. Washington, Dc, Association of Official Analytical Chemists, vol. 7, pp. 56-132, 2005.

[19] S. B. Oyeleke, and S. B. Manga, "Essentials of Laboratory Practicals in Microbiology" Tobest publisher, Minna, Nigeria, 36-75, May, 2008.

[20] M. O. Fawole, and B. A. Oso, "Laboratory manual of microbiology," $5^{\text {th }}$ Edition, spectrum Books Limited, Ibadan, pp. 22-23, Aug. 2007.

[21] S. M. Mohammed, A. A. Abdurrahman and M. Attahiru, "Proximate Analysis and Total Lycopene Content of Some Tomato Cultivars Obtained from Kano State, Nigeria," Chem Search Journal, vol. 8, no. 1, pp. 64 - 69, June, 2017. http://dx.doi.org/10.4314/csj.v8i1.9

[22] O. S. Omoba and U. Onyekwere, "Postharvest physicochemical properties of cucumber fruits (Cucumber sativus L) treated with chitosan-lemon grass extracts under different storage durations," African Journal of Biotechnology, vol. 15, no. 50, pp. 2758-2766, Dec. 2016. https://doi.org/10.5897/AJB2016.15561

[23] S. Rowshon, A. S. P. Mohammed, S. Arif, I. S. Shagata, R. Shahidur, R. Atikur, H. Abdul and H. Alamgir, "Health promoting pigments and bioactive compounds of six vegetables grown in Bangladesh," Asian Journal of Medical and Biological Research, vol. 5, no. 4, pp. 280-285, Dec. 2019. https://doi.org/10.3329/ajmbr.v5i4.45265

[24] C.B. Olalude, F.O. Oyedeji, and A.M Adegboyega, "Physico-Chemical Analysis of Daucus Carota (Carrot) Juice for possible industrial applications," Journal of Applied Chemistry, vol. 8, pp. 110-113, Aug. 2015. https//doi.org/10.9790/5736-0882110113

[25] F. Dima, D. Istrati, M. Garnai, and V. Serea, "Study on obtaining vegetables juices with high antioxidant potential, preserved by ohmic pasteurization," Journal of Agro alimentary Process and Technology Vol. 21, pp. 67-74, Jan. 2015.

[26] P. Viswanathan, and R. Kaur, "Prevalence and growth of pathogens on salad vegetables, fruits and sprouts," International Journal of Hygiene and Environmental Health, vol. 203, pp. 3,205-213, Mar. 2001. https://doi.org/10.1078/S1438-4639(04)70030-9

[27] M. M. Raja, A. Raja, M. S. Hajee, and S. A. Mohamed, "Screening of bacterial compost from spoiled vegetables and fruits and their physiochemical characterization," International Food Research Journal, vol. 19, no. 3, pp. 1193-1198, 2012.

[28] A. Kumar, V. Bhushan, S. Verma, G. Srivastav and S. Kumar, "Isolation and Characterization of Microorganisms Responsible for Different Types of Food Spoilages," International Journal of Research in Pure and Applied Microbiology, vol. 1, no. 2, pp. 22-31, 2011.

[29] C. S. Mbajiuka, E. I. Obeagu, K. C. Ochei, and D. C. Nnadi, "The Antibacterial Activity of Leaf Extracts of Ocimum gratissimum and Sida acuta," International Journal of Microbiological Research, vol. 5, no. 2, pp. 124-129, June, 2014. htpps://doi.org/10.5829/idosi.ijmr.2014.5.2.84150

[30] E. Li- Cohen, and C. M. Bruhn, "Safety of consumer handling of fresh produce," Journal of food production, vol. 65, no.8, pp. 12871297, Aug. 2002. https://doi.org/10.4315/0362-028x-65.8.1287

[31] T.A.A. Nasrin, M.A. Rahman, M.N. Islam, M.S. Arfin and L. Akter, "Effect of edible coating on postharvest quality of bell pepper at ambient storage," Bull. Institute of Tropical Agriculture, Kyushu University, vol. 41, pp. 73-83, Jan. 2018. https://doi.org/10.11189/bita.41.73 
AJIBOYE Adeyinka Elizabeth et al., Adv. J. Grad. Res.; Vol. 8, Issue 1, pp: 82-90, July 2020

[32] D.J. Udoh, B. A. Ndon, P. E. Asuquo, and N. U. Ndaeyo, “Crop Production Techniques for the Tropics," Concept publications limited, Lagos, Nigeria, pp. 238-399, 2005.

[33] P. R. Rokaya, D. R. Baral, D. M. Gautam, A. K. Shrestha and K. P. Paudyal, "Effect of Postharvest Treatments on Quality and Shelf Life of Mandarin (Citrus reticulata Blanco)," American Journal of Plant Sciences, vol. 07, pp. 1098-1105, May, 2016. https:10.4236/ajps.2016.77105

[34] D. Martinez-Romero, N. Alburquerque, J. Valverde, F. Guillen, S. Castillo, D. Valero, and M. Serrano, "Postharvest sweet cherry quality and safety maintenance by Aloe vera treatment: A new edible coating," Postharvest Biology and Technology, vol. 39, no. 1, pp. 93-100, Jan. 2006. https://doi.org/10.1016/j.postharvbio.2005.09.006

[35] R. Ortega-Toro, S. Collazo-Bigliardi, J. Roselló, P. Santamarina and A. Chiralt, "Antifungal starch-based edible films containing Aloe vera," Food Hydrocoll., vol. 72, pp. 1-10, 2017

[36] P. Talens, R. Pérez-Masía, M. J. Fabra, M. Vargas and A. Chiralt, "Application of edible coatings to partially dehydrated pineapple for use in fruit cereal products," Journal of Food Engineering, vol. 112, pp. 86-93, Sept. 2012. https://doi.org/10.1016/j.jfoodeng.2012.03.022

[37] A. Perdonesa, L. Sánchez-Gonzáleza, A. Chiralt, and M. Vargas, "Effect of chitosan-lemon essential oil coatings on storage-keeping quality of Strawberry," Postharvest Biology Technology, vol. 70, pp. 32-41, Aug. 2012. https://doi.org/10.1016/j.postharvbio.2012.04.002

[38] K. V. Sucharitha, A. M. Beulah, and K. Ravikiran, "Effect of chitosan coating on storage stability of tomatoes (Lycopersiconesculentum Mill)," International Food Research Journal, vol. 25, no.1, pp. 93-99, Feb. 2018.

[39] M. S. Hossain, and A. Iqbal, "Effect of shrimp chitosan coating on postharvest quality of banana (Musa sapientum L.) fruits," International Food Research Journal, vol. 23, no. 1, pp. 277-283, 2016.

[40] C. O. Adetunji, I. S. Afolabi, J. B. Adetunji, "Effect of rhamnolipid-Aloe vera gel edible coating on post-harvest control of rot and quality parameters of 'Agege Sweet' orange," Agriculture and Natural Resources, vol. 53, pp. 364-372, Aug. 2019. https://doi.org/10.34044/j.anres.2019.53.4.06

\section{Publish your books with AIJR publisher-}

Publish with ISBN and DOI.

$\checkmark$ Publish Thesis/Dissertation as Monograph.

$\checkmark$ Publish Book Monograph.

$\checkmark$ Publish Edited Volume/ Book.

$\checkmark$ Publish Conference Proceedings

$\checkmark \quad$ Retain full copyright of your books. Submit your manuscript at books.aijr.org

\section{Publish your research article in AIJR journals-}

$\checkmark \quad$ Online Submission and Tracking

$\checkmark$ Peer-Reviewed

$\checkmark$ Rapid decision

$\checkmark \quad$ Immediate Publication after acceptance

$\checkmark \quad$ Articles freely available online

$\checkmark \quad$ Retain full copyright of your article.

Submit your article at journals.aijr.in 